\title{
DEVELOPMENT OF THE REAL-TIME PCR METHOD FOR DETECTING Lactobacillus acidophilus IN SOME FUNCTIONAL FOODS MATRICES
}

\author{
Dang Thi Huong, Nguyen Thanh Trung ${ }^{1}$, Pham Nhu Trong, Tran Hong Ba, Le Thi Hong Hao \\ National Institute for Food Control
}

(Received on: 18/4/2019; Revised on: 24/5/2019; Accepted: 31/5/2019)

\section{Abstract}

Tn the past decades, Lactobacillus species have been widely used in the market because they are thought to have biological properties and beneficial health effects. Conventional microbiological methods are often time consuming and labor-intensive. Real-time polymerase chain reaction (PCR) method will allow to identify and quantify rapidly Lactobacilli probiotics in food. In this study, the thermal shock protein target region (hsp60) was used to identify Lactobacillus acidophilus species. The limit of detection, specificity, and accuracy were of $10^{4}, 100 \%, 100 \%$, respectively. This method is appropriate for application of detection of L. acidophilus bacteria in serveral food supplements.

Keywords: Real-time PCR, Lactobacillus acidophilus

\section{INTRODUCTION}

Lactobacillus acidophilus, a member of the group of lactic acid bacteria, is Gram-positive, rod-shaped, non-spore-forming, capable of aerobic and anaerobic fermentation, often present in the small intestine and helps balance the intestinal microflora. It is also considered a natural antibiotic against harmful microorganisms [5]. Lactobacilli strains with biological effects have been widely used in dairy products, such as yogurt as well as in food and pharmaceutical additives [2]. The variety of probiotic products available on the market is clear evidence of the health benefits of having those microbes in the body. Probiotics are defined as living micro organisms that bring health benefits to the host when administered in adequate amounts. For quality management reasons and in accordance with the European Health Requirements Regulation (EC 2007), a diagnostic tool is needed to identify and quantify beneficial bacterial strains in food. Currently, despite the economic impact, most of the tests being used to determine lactobacilli and employing conventional microbiological methods are often time-consuming, not easily standardized and sometimes error-prone. These methods include morphology, Gram staining and biochemical tests such as carbohydrate fermentation, grown at different temperatures and different salt concentrations. Morphological screening seems to be especially problematic for differentiation because lactobacilli are known to take different forms in the same species. Therefore, a quick and reliable identification tool is necessary, which uses genome characteristics to determine microorganisms at the species level: Realtime PCR. This method may allow rapid determination and quantification of Lactobacilli probiotics in food and can be applied for management and quality purposes. Real-time quantitative PCR represents a tool that has been established to specify and quantify species within a short time and is readily available in many laboratories [1]. In this study, the research group employed the heat shock protein target region (HSP60) to identify Lactobacillus acidophilus species. This protein region has been successfully used to access the identity of other bacteria.

\section{${ }^{1}$ Tel:0349363269_Email: nguyenthanhtrung83@gmail.com}




\section{MATERIALS AND METHODS}

\subsection{Research subject}

Functional food products (nuggets, etc.)

\subsection{Materials, chemicals, equipment}

\subsubsection{Materials}

Reference strains: Lactobacillus acidophilus ATCC 4356, Bifidobacterium longum V57, Bifidobacterium animalis V76.

Lactobacillus phantarum, Lactobacillus paracasei, Lactobacillus casei V53, Lactobacillus rhamnosus V51, Lactobacillus acidophillus, Bifidobacterium lactic V59, Bifidobacterium longum, Bifidobacterium buve, Streptococcus facium, Lactococcus lactic, Bifidobacterium longum.

Sample isolation source: Varied food supplements.

\subsubsection{Primary chemicals}

TNES extraction buffer solution (Sigma); Proteinase K 20 mg/ml (Sigma), PowerUp SYBR Green master mix (Appliedbiosystems), ethanol, or Gene JET genomic DNA extraction kit from Thermo Fisher Scientific (code K0722), 100bp DNA ladder.

\subsubsection{Equipment}

Real-time PCR equipment CFX96 (Biorad), Nanodrop1000 (Thermo Scientific), Mikro 200 (Hettich) cold centrifuge, thermal blocks (Labnet), and other accessories.

\subsection{Research methods}

DNA extraction: the method employed highly concentrated salt (high salt) or Gene JET kit. After homogenizing the samples, protease $\mathrm{K}$ was added to $50-100 \mathrm{mg}$ of samples and incubated at $55^{\circ} \mathrm{C}$ within five hours. DNA was collected using $100 \%$ ethanol.

The solution after OD extraction from 1.8 to 2.0 was used for real-time PCR analysis.

Real-time PCR for amplification of the target gene: The pair of primers in use is presented in Table 1.

Table 1. Sequence species-specific primers based on hsp60 gene

\begin{tabular}{|c|c|c|c|c|c|}
\hline Species & Primer & $\begin{array}{c}\text { Size of } \\
\text { amplicon } \\
\text { (bp) }\end{array}$ & $\begin{array}{c}\text { Melting } \\
\text { temp }(C)\end{array}$ & Target & Reference \\
\hline L. acidophilus & $\begin{array}{l}\text { LAcidoF: 5'-CTT TGA CTC } \\
\text { AGG CAA TTG CTC GTG AAG } \\
\text { GTA TG - 3' } \\
\text { LAcidoR: 5'-CAA CTT CTT } \\
\text { TAG ATGCTGVAAG AA CAG } \\
\text { CAG CTA CG-3'. }\end{array}$ & 191 bp. & $\begin{array}{c}80.5^{\circ} \mathrm{C} \pm \\
0.5^{\circ} \mathrm{C}\end{array}$ & hsp60 & $\begin{array}{l}\text { Herbel SR1 and } \\
\text { colleagues [1] }\end{array}$ \\
\hline
\end{tabular}

Table 2. Amplification reaction mixture in the final volume/ concentration per reaction vial

\begin{tabular}{|c|c|}
\hline $\begin{array}{c}\text { PowerUp SYBR Green } \\
\text { master mix, 2X }\end{array}$ & $10 \mu \mathrm{l}$ \\
\hline Sample DNA & $1 \mu \mathrm{l}$ \\
\hline Forward primer & $1 \mu \mathrm{l}$ \\
\hline Reverse primer & $1 \mu \mathrm{l}$ \\
\hline Water added & $20 \mu \mathrm{l}$ \\
\hline
\end{tabular}


Table 3. Procedure: Reaction conditions

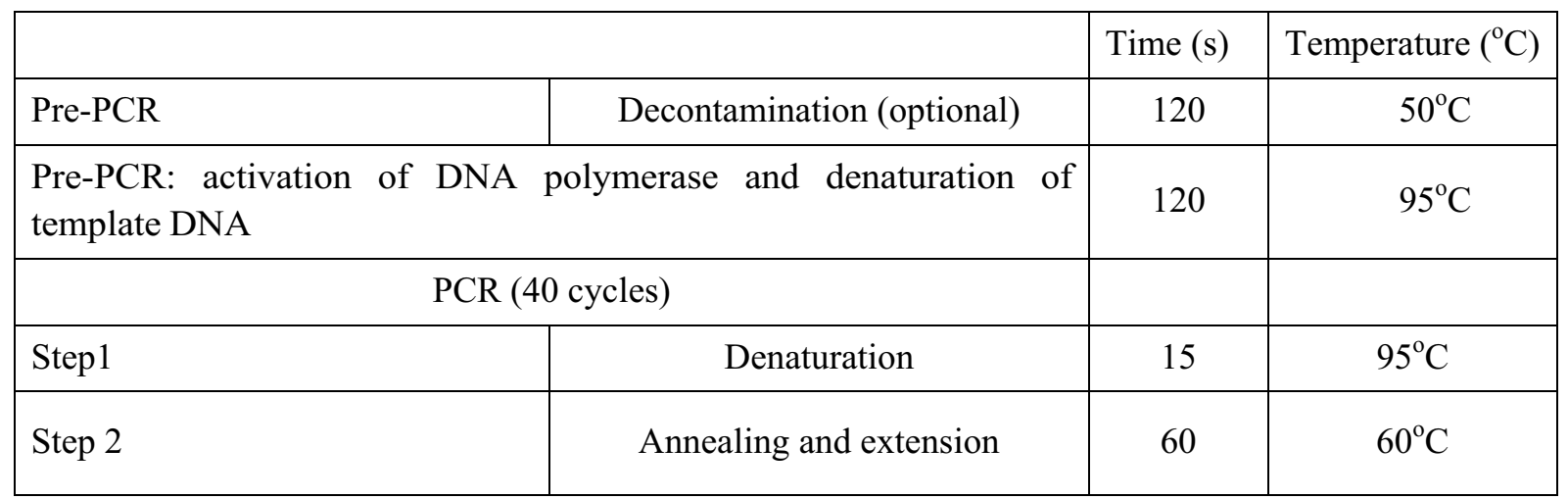

Method validation [3, 4]: Validation of limit of detection (LOD), accuracy (AC), specificity (SP), sensitivity (SE) can be specified with the following formular:

$$
\begin{gathered}
\mathrm{AC}=\frac{\mathrm{TP}+\mathrm{TN}}{\mathrm{N}} \times 100 \quad \mathrm{SE}=\frac{\mathrm{TP}}{\mathrm{TP}+\mathrm{FN}} \times 100 \\
\mathrm{SP}=\frac{\mathrm{TN}}{\mathrm{TN}+\mathrm{FP}} \times 100
\end{gathered}
$$

Where:

AC: Accuracy; SE: Sensitivity; SP: Specificity; TP: True positive; TN: True negative; FP: False positive; FN: False negative; N: total number of samples analyzed

\section{RESULTS AND DISCUSSIONS}

\subsection{DNA extraction}

Reference strains and microbiological samples were extracted by Gene JET DNA extraction kit, DNA products were tested for concentration on Nanodrop. The content was from 2 to $16 \mathrm{ng} / \mu 1$, and high concentration of salt was from $200-500 \mathrm{ng} / \mu \mathrm{l}$, purity was in the range of 1.8 to $2.1 \mathrm{ng} / \mu 1$, the content and purity were ensured to be the template for real-time PCR reaction.

\subsection{Limit of Detection (LOD)}

LOD of the method is the lowest concentration of micro-organisms in the sample, where at least $90 \%$ of the samples is positive. To test the LOD, the sample was decimally diluted from the oncentration of $10^{-1}$ to $10^{-7} \mathrm{CFU} / \mathrm{mL}$, each dilution was duplicated, the result was shown in Figure 1.

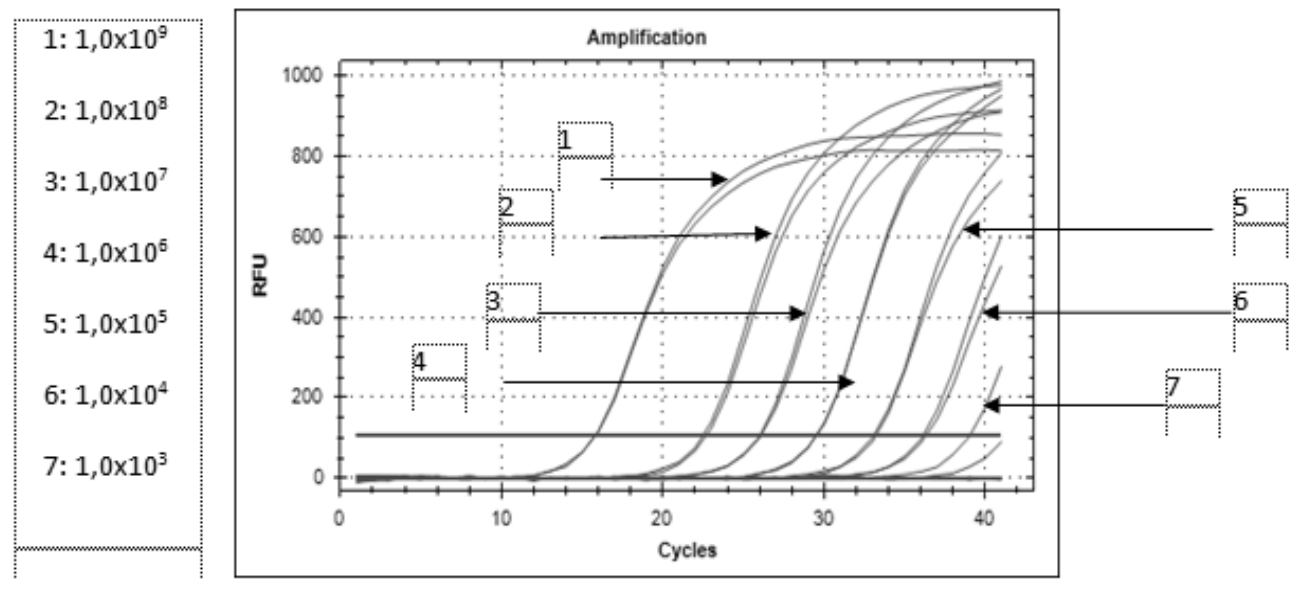

Figure 1. Method detection limit survey result 


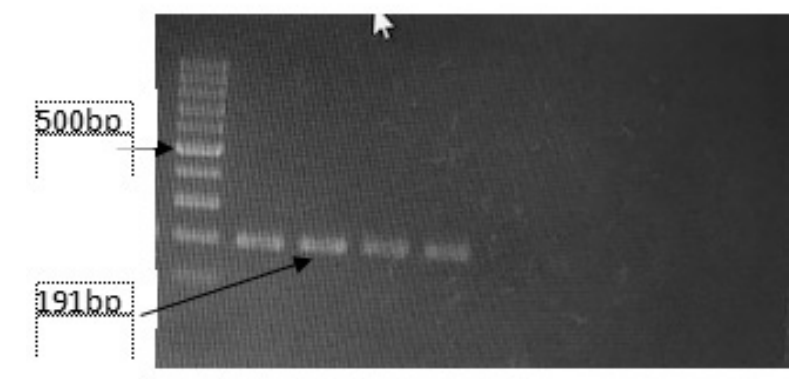

Figure 2. Electrophoresis image at $10^{5}, 10^{4}, 10^{3}$, from left to right respectively

Comment: The amplification result showed that microbiological concentration of $10^{3}$ at one time gave negative value and at another time, the value of $\mathrm{Ct}=39.06$ (40 cycles) and the electrophoresis image did not contain any band of $191 \mathrm{bp}$. Hence, the highest probability of positive result when repeating 10 times will be $80 \%(<90 \%)$. The survey at the microbial concentration of $10^{4}$ was additional conducted. The results obtained were shown in Figures 3, 4.

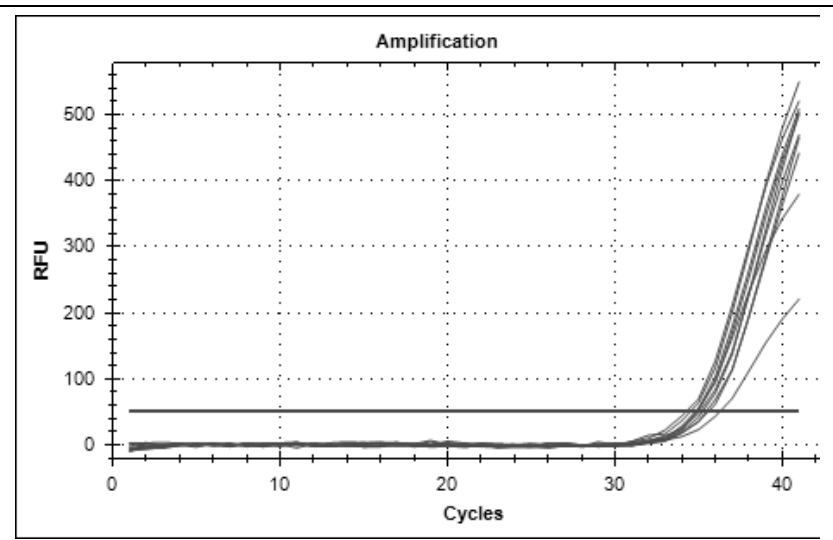

\begin{tabular}{|c|c|c|c|c|c|}
\hline Well $\Delta$ & Fluor $\Delta$ & Target $\Delta$ & Content $\Delta$ & Sample $\Delta$ & $\mathrm{Cq}$ \\
\hline $\mathrm{CO} 1$ & SYBR & & Unkn & $10^{\wedge} 4$ & $35 . C$ \\
\hline $\mathrm{CO} 2$ & SYBR & & Unkn & $10^{\wedge} 4$ & 35.5 \\
\hline $\mathrm{CO} 3$ & SYBR & & Unkn & $10^{\wedge} 4$ & 34.5 \\
\hline $\mathrm{CO} 4$ & SYBR & & Unkn & $10^{\wedge} 4$ & $34 . \varepsilon$ \\
\hline $\mathrm{CO5}$ & SYBR & & Unkn & $10^{\wedge} 4$ & 35.6 \\
\hline $\mathrm{CO6}$ & SYBR & & Unkn & $10^{\wedge} 4$ & 34.2 \\
\hline $\mathrm{CO} 7$ & SYBR & & Unkn & $10^{\wedge} 4$ & 35.2 \\
\hline $\mathrm{CO8}$ & SYBR & & Unkn & $10^{\wedge} 4$ & 35.1 \\
\hline D01 & SYBR & & Unkn & $10^{\wedge} 4$ & 36.2 \\
\hline D02 & SYBR & & Unkn & $10^{\wedge} 4$ & 34.5 \\
\hline
\end{tabular}

Figure 3. Amplified image and threshold value (Ct)

of L. acidophilus for 10 times at microbial concentration of $10^{4}$

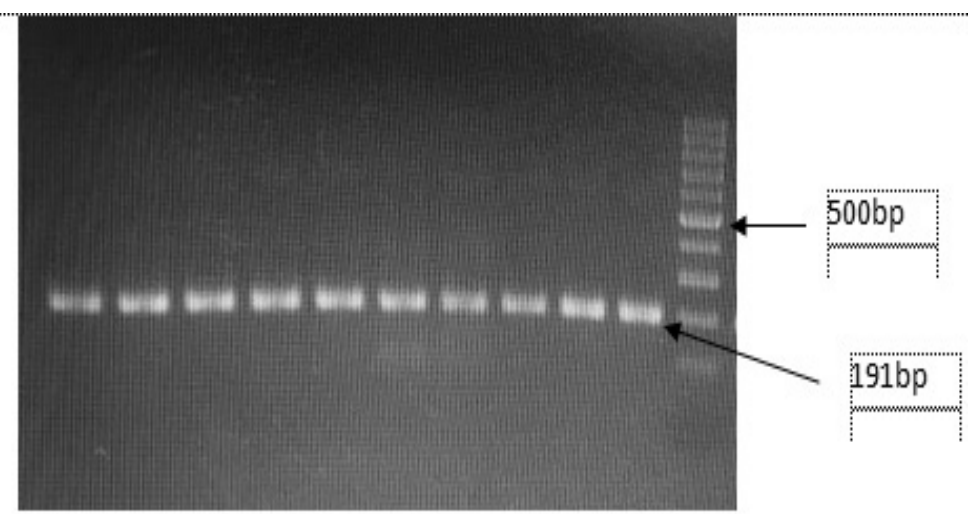

Figure 4. Electrophoresis result DNA size of L.acidophilus bacteria (191bp)

From the above results, the probability of positive result at the concentration of $10^{4} \mathrm{CFU} / \mathrm{mL}$ microorganisms and was of $100 \%$. Therefore, the detection limit of the method (LOD) was $10^{4} \mathrm{CFU} / \mathrm{mL}$.

\subsection{Accuracy (AC), specificity (SP) and sensitivity (SE)}

Prepare three sample groups: Lactobacillus acidophilus strain, mixture of 10 microorganisms (mix 10 bags including: Lactobacillus phantarum, Lactobacillus paracasei, Lactobacillus casei, Lactobacillus. rhamnosus, Lactobacillus acidophillus, Bifidobacterium lactic, Bifidobacterium longum, Bifidobacterium buve, Streptococcus facium, Lactococcus lactic, Bifidobacterium longum). 
The analysis was repeated twice, the results were displayed in Figure 5.
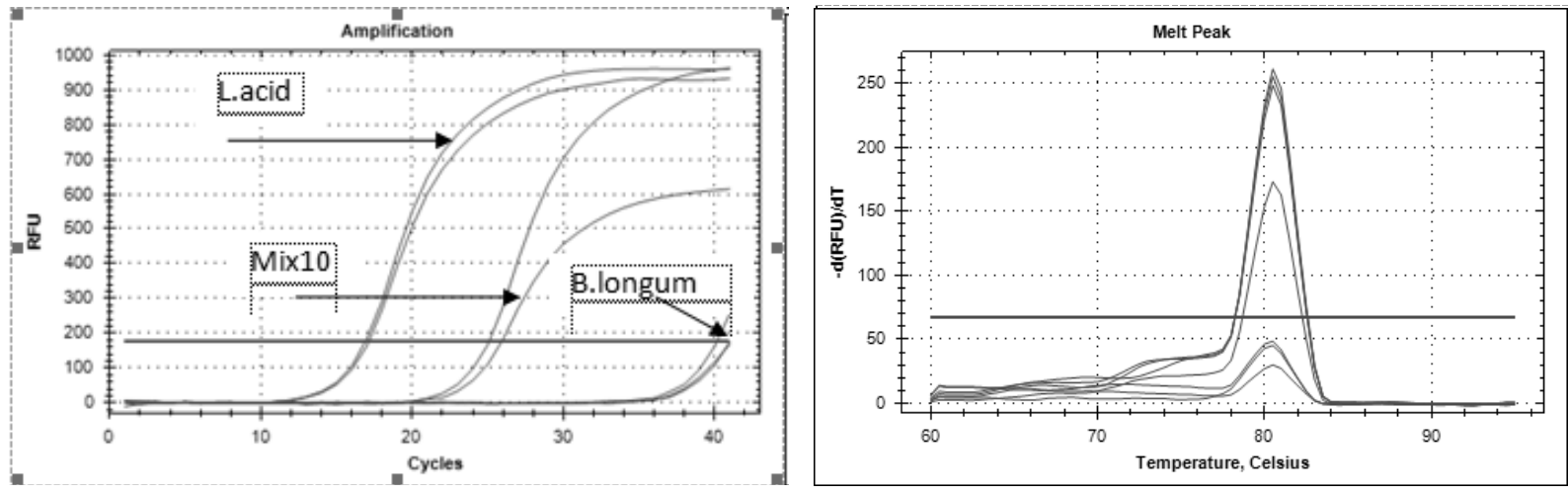

Figure 5. Sample analysis results of $A C, S E, S P$

According to the results in Figure 5, accuracy (AC), specificity (SP), sensitivity (SE) were all $100 \%$, LOD was also consistent with Herbel et al's research [7].

\subsection{Analysis of actual samples}

The method was applied to identify some of the commercial functional food products from the market including:

- Probiotics: Lactomin plus (code 6668dv1): including on three bacteria species Lactobacillus acidophilus, Lactobacillus plantarum, Bifidobaterium animalis subsp. lactis

- Probiotics: Lactomin (code 6668dv2): including on three bacteria species Lactobacillus acidophilus, Lactobacillus plantarum, Bifidobaterium animalis subsp. lactis

- Gabulin probiotics tablet (code 6735dv4): including on two bacteria species: Bacilus subtilis, Lactobacillus acidophilus.

Results of the analysis were given in Figures 6 and 7.

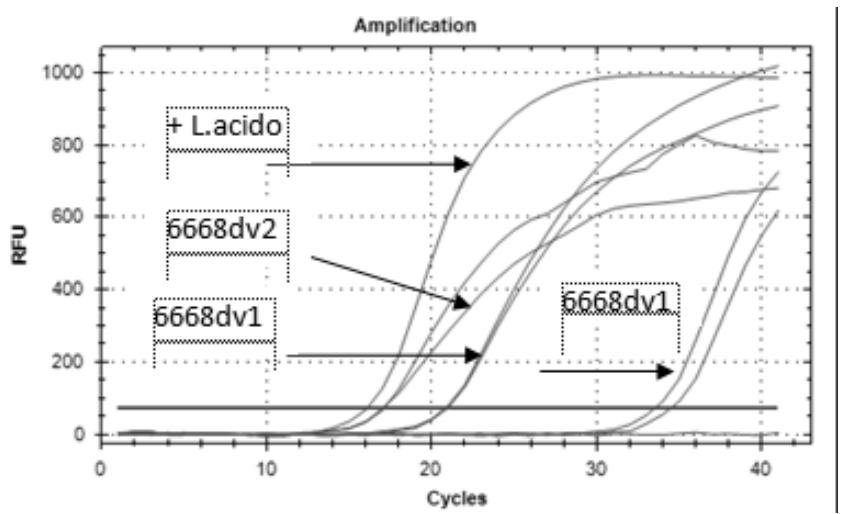

\begin{tabular}{|c|c|c|c|c|c|}
\hline Well $\Delta$ & Fluor $\Delta$ & Target $\diamond$ & Content $\diamond$ & Sample $\Delta$ & $\mathrm{Cq} \Delta$ \\
\hline B01 & SYBR & & NTC & & N/A \\
\hline BO2 & SYBR & & Unkn & L.a & 16.12 \\
\hline $\mathrm{BO3}$ & SYBR & & Unkn & $6668 \mathrm{dv} 1$ & 20.85 \\
\hline B04 & SYBR & & Unkn & $6668 \mathrm{dv} 1$ & 21.02 \\
\hline B05 & SYBR & & Unkn & $6668 \mathrm{dv} 2$ & 17.16 \\
\hline B06 & SYBR & & Unkn & $6668 \mathrm{dv} 2$ & 17.07 \\
\hline B07 & SYBR & & Unkn & $6735 \mathrm{dv} 4$ & 34.55 \\
\hline B08 & SYBR & & Unkn & $6735 \mathrm{dv} 4$ & 33.57 \\
\hline
\end{tabular}

Figure 6. Amplification results and Ct threshold of samples

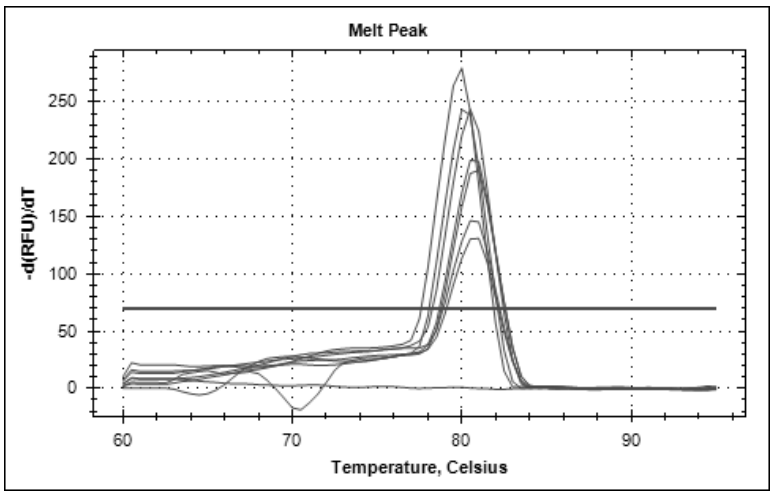

\begin{tabular}{|c|c|c|c|c|c|}
\hline Well $\diamond$ & Fluor $\quad \Delta$ & Target $\Delta$ & Content $\Delta$ & Sample $\Delta$ & $\underset{\text { Temp }}{\text { Melt }} \diamond$ \\
\hline B01 & SYBR & & NTC & & None \\
\hline $\mathrm{B} 02$ & SYBR & & Unkn & L.a & 80.50 \\
\hline $\mathrm{BO} 3$ & SYBR & & Unkn & $6668 \mathrm{dv} 1$ & 80.00 \\
\hline $\mathrm{BO4}$ & SYBR & & Unkn & $6668 \mathrm{dv} 1$ & 80.00 \\
\hline B05 & SYBR & & Unkn & $6668 \mathrm{dv} 2$ & 80.50 \\
\hline B06 & SYBR & & Unkn & $6668 \mathrm{dv} 2$ & 81.00 \\
\hline B07 & SYBR & & Unkn & $6735 \mathrm{dv} 4$ & 81.00 \\
\hline B08 & SYBR & & Unkn & $6735 \mathrm{dv} 4$ & 80.50 \\
\hline
\end{tabular}

Figure 7. Melt curve peak chart and melting cuver temperatre on samples 
The results showed that all three samples supplemented with Lactobacillus acidophilus DNA were amplified and melted within the permitted range $(80.5 \pm 0.5)$.

\section{CONCLUSIONS}

The study has successfully developed a real-time PCR method to detect L. acidophilus bacteria in several functional food products with limit of detection of $104 \mathrm{CFU} / \mathrm{mL}$, sensitivity of $100 \%$, specificity of $100 \%$, and accuracy of $100 \%$. This is a suitable method for detection of L. acidophilus bacteria in functional food products.

\section{REFERENCES}

1. Herbel SR1, Lauzat B, von Nickisch-Rosenegk M, Kuhn M, Murugaiyan J, Wieler LH, Guenther S (2013), "Species-specific quantification of probiotic lactobacilli in yoghurt by quantitative real-time PCR", Journal of Applied Microbiology, ISSN 1364-5072.

2. Monique Haarman and Jan Knol (2006), "Quantitative Real-Time PCR Analysis of Fecal Lactobacillus Species in Infants Receiving a Prebiotic Infant Formula", Appl Environ Microbiol, 72(4): 2359-2365.

3. Tran Cao Son (2010), Assessment of methods in chemical and microbiological analysis, Science and Technology Publishing House, Hanoi.

4. Office of Quality Accreditation (2016), Additional requirements for accrediting field testing laboratories.

5. Jana Junick and Michael Blaut (2012), "Quantification of Human Fecal Bifidobacterium Species by Use of Quantitative Real-Time PCR Analysis Targeting the groEL Gene", Department of Gastrointestinal Microbiology, German Institute of Nutrition Potsdam-Rehbruecke, Nuthetal, Germany.

6. Herbel SR, Von Nickisch-Rosenegk M, Kuhn M, Murugaiyan J, Wieler LH and Guenther S1 (2014), "Specific TaqMan Probes for the Identification and Quantification of Lactobacilli in Pharmaceuticals", Probiotics \& Health.

\section{Tóm tắt}

\section{XÂY DƯंNG PHƯƠNG PHÁP PHÁT HIÊN LACTOBACILLUS ACIDOPHILUS BẰNG REAL-TIME PCR TRONG MỘT SỐ NỀN THỰC PHẨM CHỨC NĂNG}

\section{Đặng Thị Huờng, Nguyễn Thành Trung, Phạm Như Trọng, Trần Hồng Ba, Lê Thị Hồng Hảo \\ Viện Kiểm nghiệm An toàn Vệ sinh thực phẩm Quốc gia}

Trong những thập kỷ qua, các loài Lactobacillus đã được sử dụng rộng rãi trên thị trường vì chúng được cho là có đặc tính sinh học và có tác dụng tốt cho sức khỏe. Các phương pháp vi sinh cổ điển, thường tốn thời gian, tốn nhiều công sức, cho kết quả chậm. Phương pháp phản ứng chuỗi polymerase thời gian thực (PCR) cho phép nhanh chóng xác định và định lượng men vi sinh Lactobacilli trong thực phẩm. Trong nghiên cứu hiện tại, chúng tôi đang sử dụng vùng protein sốc nhiệt đích (hsp60) để xác định loài Lactobacillus acidophilus. Giới hạn phát hiện, độ đặc hiệu, độ chính xác lần lượt là 104,100\%,100\%. Phương pháp thích hợp để áp dụng phát hiện vi khuẩn L. acidophilus trong một số thực phẩm bổ sung.

Tù khóa: Real-time PCR, Lactobacillus acidophilus 